Oddelek za klasično filologijo,

Filozofska fakulteta Univerze v Ljubljani

Slovenija

\title{
GNOSTICISM AND ALCHEMY IN THE VIRGIN MARTYR IDEAL OF HROTSVIT OF GANDERSHEIM
}

\begin{abstract}
. - Članek raziskuje versko in filozofsko ozadje lika deviške mučenke v dramskih delih Hrotswithe iz Gandersheima. V nekaterih njenih delih je mogoče opaziti vplive apokrifnih spisov, ki jih priznava tudi sama, pričujoči članek pa se osredotoča na manj vidne dokaze tega vpliva, ki se kaže v skoraj nadčloveškem (ali nečloveškem) liku deviške mučenke $v$ njenih dramskih delih. Ta lik se navdihuje pri poznoantičnih portretih mučencev, upodobitev njihovega trpljenja pa je bila pogosto del polemike med ortodoksnimi kristjani in pripadniki nekaterih gnostičnih sekt, ki se s prvimi niso strinjali glede nekaterih temeljnih vprašanj, kot so na primer Kristusov fizični obstoj, (ne)uničljivost in vstajenje telesa ter posledično smisel in vrednost mučeništva. Hrotswithini liki mučenih devic se navdihujejo pri številnih antičnih in srednjeveških poročilih, ki lik mučenca praviloma idealizirajo. Po drugi strani pa $\mathrm{v}$ teh poročilih zasledimo še drugačen ideal, in sicer takšnega, ki oznanja nedotakljivost ne le duše, temveč - do neke mere -tudi telesa. V mučilnem postopku, ki v nekaterih pogledih spominja na alkimistično "mučenje « materije, se telo mučenca bodisi spremeni (ali celo izpopolni) bodisi ostane povsem nedovzetno za vsakršno mučenje ali oskrunjenje. Zato nas ne preseneti, da mučenec tudi $\mathrm{v}$ duhovnem smislu v obeh primerih ostane trden in nedovzeten za to, kar se godi z njim. Prav ta neomajni duh, ki se smeje svojemu mučitelju, nas nehote spomni na duhovno komponento nekaterih oseb, ki jih najdemo $\mathrm{v}$ gnostičnih opisih Kristusovega trpljenja, pa tudi v preizkušnjah ženskih likov, na primer Eve, ki se oskrunjenju izmakne tako, da svoje duhovno bistvo loči od telesa, ki ga prepusti napadalcem. Telo deviške mučenke nazadnje le podleže smrti (pogosto v ognju), vendar je njegovo uničenje nujno za osvoboditev duše, ki se želi vrniti k Bogu.
\end{abstract}

\section{Impassive Virgins}

The virgin martyr ideal plays an important role in Medieval martyrology, particularly in the monastic communities which revered and imitated the ideal of virginity itself. ${ }^{1}$ Hrotsvit, although not a nun strictly

${ }^{1}$ The popularity of this ideal is perceivable in the transformation of certain legends in which the protagonists had originally not been cast as virgins. Winstead (Virgin Martyrs, 9-12) points out the deeper meaning of these legends, containing elements of some of the greatest Christian mysteries (virgin birth, for example). In these stories, Chris- 
speaking, ${ }^{2}$ was no exception. Many of her works, relying on rich sources of late Antique and Medieval legends of the saints, honor this ideal. ${ }^{3}$ She approaches it in two ways: Either through its dark contrast, the fallen woman, who eventually returns to this ideal through conversion, ${ }^{4}$ or which is the subject of this article - through the martyr figure of an innocent girl, sometimes no more than a child who, faithful to her God, is willing to suffer torture and death without hesitation. Both types of characters undergo a transformation of either soul or body and, in both cases, the path that leads this woman to God is painful and frequently leads to martyrdom.

My research will focus on the first type, the virgin martyr, a recurring figure in the Medieval Lives and Deeds of the Saints (Acta). Virgins held a special place among martyrs, since their ordeals were frequently intensified by implicit or explicit threats to their virginity. ${ }^{5}$ Hrotsvit has fully explored this subject in two of her dramatic works (Dulcitius and Sapientia), as well as in a poem describing the sufferings and death of St. Agnes (Passio sanctae Agnetis virginis et martyris). Neither her subjects nor her treatment of them is very original. There is, however, the preference of certain motifs and the approach to them which are worth noticing, particularly in both plays, Dulcitius and Sapientia. In these works, she created, or should we say recreated, six (seven, counting Agnes) protagonists in very similar plots, which display general features of the virgin martyr drama: Because of their Christianity, the girls are condemned to torture which, with the exception of Spes and Fides in the Sapientia, involve the threat of rape. They all show unwavering faith and undertake unhuman tortures without visible distress. They all embrace death as a reward for their faithfulness, and rejoice in its promise to lead them to God. They also share an uncommon physical attraction, which excites the admiration and lust (the latter especially in Agnes case, where it is the main cause of her trials) of their persecutors, an admiration that never fails to degenerate into a rancorous rage, leading often into the attempt of viola-

tianity and virginity merged into a virgin ideal that assumed a prominent role in martyr legends (see also Sarah Salih, Versions of Virignity, 47-50).

${ }^{2}$ She was a canoness of presumably aristocratic origins in the Benedictine monastery of Gandersheim in Saxony.

${ }^{3}$ Whether this means that virginity is a central theme of her plays is another question, addressed by Wailes in "Beyond Virginity: Flesh and Spirit in the Plays of Hrotsvit of Gandersheim," 1-3.

${ }^{4}$ In the Bible, the harlot can be a symbol of the betrayal of God, while with the Church fathers, she adopts a more specific character of the fallen Eve, who was believed to have seduced the first Man to the sin of flesh. Her journey of return to the ideal of the Virgin Mary is a popular theme in the legends of the desert fathers (see Coon, Sacred Fictions, 71-94). Hrotsvit has also used this motif in two of her plays, Abraham (on Mary, Abraham's niece) and Paphnutius (on the conversion of Thais). For the sources and uses of this motive, see Karras, Holy Harlots (on Hrotsvit in particular, see 11-13).

${ }^{5}$ Winstead, Virgin Martyrs, 12. 
tion of the heroine(s). ${ }^{6}$ In Dulcitius and Sapientia in particular, we find an almost mechanical plot $^{7}$ that follows the prescribed structure of these legends: ${ }^{8} 1$. The judge faces the heroine; 2 . He demands of her an act of sacrifice to pagan gods; 3 . When she refuses, he first coaxes and then threatens her; and 4. He relinquishes her to torture and death.

The virgin martyr legends frequently dwell on the inviolability of the saints' virginity, displayed by the fact that their persecutors are unable even to get them naked, let alone rape them. ${ }^{9}$ At the very point which should make them more vulnerable than their fellow martyrs, they prove to be invincible ${ }^{10}$ even though they are susceptible (up to a point) to torture and, undoubtedly, to death. The scenes of torture are most unrealistic, but that again is typical for the medieval martyr legends, which often describe apparent immunity to physical pain, frequently accompanied by a miraculous invulnerability of the body. These characteristics became more pronounced with the passing of the centuries: The $13^{\text {th }}$ century collection of the legends of the saints by James of Voragine (The Golden Legend) is full of horrific (to the point of being absurd) scenes of torture rendered even more incredible by the total insensibility of the saints. ${ }^{11}$ We read, for example, about St. Christine who, when the judge orders her bones to be broken and her body to be torn up by hooks, is able to pick up the pieces of her flesh and throw them into his face. Thrown into the sea with a stone tied around her neck, she is lifted up by angels. After her return, her breasts are cut off (with milk flowing out). Then, she is thrown into the fiery furnace, where she remains for five days, unharmed, singing with angels. Unlike her judges, who begin to die on her, she is indestructible and indomitable: She is still able to speak when her tongue is torn out,

${ }^{6}$ On the role of sexuality in Hrotsvit's plays which present the virgin martyr figure, see Newman, "Violence and Virginity in Hrotsvit's Dramas," 59s.

${ }^{7}$ Hrotsvit's plays were noted for the lack of dramatic character and general human sensibility (Sticca, The Latin Passion play, 6s.). Their impersonal character is accentuated by the allegorical names of the protagonists, which is particularly the case of both above mentioned plays. Wilson, however, points out her mastery of dramatic elements (see her 'Introduction' to The Plays of Hrotsvit of Gandersheim, xxv-xxviii).

${ }^{8}$ Winstead, Virgin Martyrs, 5-8.

${ }^{9}$ In Dulcitius, they are unable to strip off the clothes of the three captives and, in the last scene, they fail to bring Irena to the brothel, due to the intervention of two mysterious strangers (p. 170, 15-20 and p. 175, 6-9 Berschin/ PL 137, 998 and 1000s.). In Agnes, the saint is stripped, but her hair, grown unnaturally long, instantly covers her naked body. And when brought to the brothel, an angel appears with a white robe for her. Moreover, she inexplicably, but successfully, repels all the attacks on her chastity ( $P L$ 137, 1125s.). On Hrotsvit's compensation of physical chastity with the spiritual one, see Newman, "Violence and Virginity," 63-65.

${ }^{10}$ As demonstrated by the thorough analysis of the passio of st. Barbara in Mills, Suspended Animation, 112-142. The reversal of the relationship, in the torture process, between the torturer and his victim, as well as its political implications are analyzed by van Elk, "'When Female Weakness Triumphs"”, 11-17.

${ }^{11}$ On James of Voragine's faith in the indestructability of the martyr's body, see Walker Bynum, Resurrection of the Body, 309-316. 
and to blind the last judge by throwing her severed tongue into his face. $^{12}$

I have taken the example of St. Christine, because it has several features in common with Hrotsvit's portraits of the virgin martyrs (e.g. milk flowing out of the Fides' cut-off nipples, and Caritas singing in the fiery furnace with angels). ${ }^{13}$ Hrotsvit's heroine also speaks with contempt of her tormentors and is insensible to torture. Even her Agnes, who by anguish and sensitivity proves to be more human than her fellow martyrs Fides, Spes and Caritas, who are clearly personifications, is immune to desecration and fire. As are Agape and Chionia, whose death at the stake is swift and painless, and Spes and Caritas, who not only remain untouched by the flames, but also see their persecutors (or near standing witnesses), burned instead. We notice that even the torments which one should expect to cause certain death leave the body unharmed. On the other hand, death is brought about by seemingly much less radical procedures, such as arrows or the sword. ${ }^{14}$ The martyr drama seems to follow a script where only a specific deed, ordered in a specific moment, ends the ordeals of the saint. Sometimes fire is the instrument of torture, as well as of death; and while it fails completely in the role of the former, it is very efficient in the role of the latter: Agape in Chionia dies in the fire that "forgot its nature" and did not even burn their hair. There is no reason for their death, but that it was ordered by their persecutor and embraced by them.

\section{The Meaning of Christ's Passion and Martyrdom of the Saints: Gnostic Perspective}

The impassibility of the body can be understood as a sign of God's grace shed on those who bear witness to His power (martyres). As such, it can be even an instrument of conversion: In Agnes, the youths that gather in the brothel with the intention to violate the heroine are not only restrained by the light that surrounds her, but are also compelled to proclaim the supremacy of her God. Physical inviolabili-

$12 \mathrm{~J}$. of Voragine, $387 \mathrm{~s}$. Earlier versions of St. Christine's legend give a more reasonable account of her ordeals: Cf., for example, Adhelm's version, which does not include the particular scene of the mutilation of the breast and the emanation of milk from the wounds (De virginitate, XLVII). We find this scene again in the Passio C. Christinae of the anonymous author, as well as in other sources of Acta sanctorum (e. g. in Elogia Graeca); but its authenticity is questioned (Acta Sanctorum 24 July, V, 496). The theme of breast mutilation was common in the female martyrs' legends; on the importance of this motif in the late Middle Ages, illustrated by the case of Osbern Bokenham's st. Agatha, see Delany, Impolitic Bodies, 106-110.

${ }^{13}$ On the socio-political character of Dulcitius and Sapientia, see Carlson, "Impasive Bodies," 473-487, where the impassivity of the virgin martyr's body is placed in the context of Hrotsvit's covert propaganda in service of the ruling class, to which she herself belonged.

14 The execution itself sometimes seems to be lost in the horrors of the torture, and is certainly anticlimactic, as Walker Bynum puts it (Resurrection of the Body, 312). 
ty of the body also makes the impassibility of the soul perfectly comprehensible. More difficult to accept is the imperturbability of the saints, in cases when their bodies do not resist the torture. Such is the case of Fides and Spes in Sapientia, where the picture of their torments is more explicit and, consequently, more unreal. These characters display more than just impassivity, for they show a kind of derisive triumph, even in view of their own mutilated bodies.

Physical suffering of the martyrs is related to the greatest Christian mystery - Christ's victory over death, his resurrection and, as a result, the resurrection of the body. With the immortality of the flesh, Christianity has crossed the indisputable philosophical line between the perishable body and the immortal soul. Their convictions had lead them to a confrontation not only with pagan philosophers, but also with some of the Christian Gnostic doctrines, where Christ's physical life did not play any major role in God's plan of salvation, nor in the mystery of his resurrection, that was seen more as a symbol of liberation of the spirit from the body. ${ }^{15}$ These Gnostics believed that the death and suffering of Christ had been inflicted on the Son of Man only, a terrestrial counterpart to the true Christ, who had never suffered nor died on the cross. ${ }^{16}$ Certain Gnostic texts, in fact, deal with this illusory Passion: In The Revelation of Peter, the Savior says to Peter: "He whom you saw on the tree, glad and laughing, this is the living Jesus. But this one into whose hands and feet they drive the nails is his fleshly part, which is the substitute being put to shame, the one who came into being in his likeness." 17 The true Jesus is essentially a spiritual being, and what is even more significant, this fact eludes his executioners. That is why, in The Second Treatise of the Great Seth, Christ laughs at their ignorance: "I did not succumb to them as they had planned. But I was not afflicted at all. ... For my death, which they think happened, happened to them in their error and blindness, since they nailed their man unto their death. Their Ennoias did not see me, for they were deaf and blind... But I was rejoicing in the height, over all the wealth of the archons and the offspring of their error, of their empty glory. And I was laughing at their ignorance." 18 Similar elements are attested to in the Gnostic revelations, featuring a female character, Eve. In The Reality of the Rulers, Eve is Adam's female counterpart, who consists of the spiritual part, the source of life, and the carnal woman, created from Adam's body. Adam's creators and rulers of the world conceive a

${ }^{15}$ Walker Binum, Resurrection of the Body, 26. For Gnostics, the divine element entrapped in the mundane part of the human being is spirit, since the soul (as well as the body) is produced by cosmic powers (for the tripartite division of man, see Jonas, The Gnostic Religion, p. 44).

${ }^{16}$ It was not a general conviction among Gnostics, since many of them defended the opposite view. These divergences could be observed even within Gnostic sects (see Pagels, The Gnostic Gospels, 90-97).

${ }^{17}$ NHC VII.3.81; transl. by J. Brashler and R. A. Bullard.

${ }^{18}$ NHC VII.2.55-56; transl. by R. A. Bullard and J. A. Gibbons. 
passion for this carnal image of the spiritual woman and defile it, while she herself changes into a tree and laughs at their blind stupidity. The same blindness leads them to attempt to violate her daughter, Norea, too, claiming "Your mother Eve came to us." She retorts that they never knew her mother, and that it was "their own female" that they knew (that is, the carnal woman, issued from the carnal man they created). ${ }^{19}$

Comparable motifs can be found in some versions of the legend of the martyrdom of Agape, Chionia and Irena. The Roman prefect Dulcitius is blinded by the passion for the three beautiful prisoners, and he sneaks into their prison with the purpose of raping them. Instead, he ends up in the kitchen, passionately embracing the pots and pans, mistaking them for the prisoners. In Hrotsvit's Dulcitius, the girls observe the scene and they laugh at him: "Look at him, the fool. He's completely out of his mind! He thinks he is embracing us!" (Irena to her sisters). ${ }^{20}$ Moreover, Dulcitius does not know his mistake until he returns home, blackened by soot, and is not recognized by his own wife. This scene was obviously part of the older tradition, for it is also included in Aldhelm's earlier version of the legend (De virginitate 50) ${ }^{21}$ There, however, the girls know nothing of Dulcitius' attempt, and therefore cannot show their contempt for his presumptuousness. In Dulcitius, on the other hand, their observations picture the scene, which may be more than just "an instance of typical medieval kitchen humor,"22 for it has been discovered to have an important symbolic function. ${ }^{23}$ Hrotsvit, moreover, dwells on the prefect's blindness, which she prolongs for a considerable time after his leaving the prison, and makes her heroines shame the prefect's stupidity. In fact, Hrotsvit's heroines, in

${ }^{19}$ See NHC II.4.89-92.

${ }^{20}$ Dulc., p. 168, 16s. Berschin (transl. by L. Bonfante)/ PL 137, 997.

${ }^{21}$ This episode does not appear in the documents that are supposed to originate from the Christian community of Thessalonica: In that version, the girls are primarily accused of hiding Christian documents, and they are condemned to be burned at the stake (see The Acts of Christian Martyrs (Musurillo ed., 280-293), Dulcitius' debacle is documented again in Bolland's Acta sanctorum (3 April, I, 248), and the scene is very similar to Hrotsvit's.

${ }^{22}$ Wilson, "The Saxon Canoness: Hrotsvit of Gandersheim," 34. Of course, there is no denying its elements of farce. Dronke's observation is that the Dulcitius stands out from among other plays by its burlesque elements, aiming to ridicule the villains of the drama (Women Writers of the Middle Ages, 61).

${ }^{23}$ See Sticca, "Hrotswitha's 'Dulcitius' and Christian Symbolism," who explains the allegorical meaning of the kitchen, representing Hell, Dulcitius, representing the Devil, and pots and pans representing the subjection to carnal passion. Opinions are divided as to the importance of this episode: Sticcas' interpretation gives it a prominent role in the plot (Ibid. 108), and this view is supported by the summary of the play, which lays a particular stress on the scene. For a different opinion, see Wailes, "Beyond Virginity," who also gives a moral interpretation of the scene as picturing the negative consequences of uncontrolled sexual passion in "Hrotsvit's Plays," 138. On socio-political implications of this scene, see Gravdal, Ravishing Maidens, 33-35. 
both plays, show great contempt for the blind ignorance of their persecutors. $^{24}$ The object of their derision is mostly the steadfast conviction of their enemies, of having control over them merely because they have imprisoned their bodies. In Sapientia, Fides, a child of twelve years,${ }^{25}$ reproaches the emperor for his lack of wisdom, and laughs at his threats of torture, foreseeing that the torture will sooner break her tormentors than herself. Hrotsvit's heroines generally tinge their indifference to their ordeals with the scorn for their executioners' stupidity, which recalls the above mentioned Gnostic motifs. Not only there is no depiction of suffering and pain in these dramas (in Sapientia in particular), but the absence of them is repeatedly brought up by the heroines, either with disdain (directed toward their murderers), or with gratitude (directed towards God): "You have wounded my untouched breast, but you have not harmed me." (Fides) "Look at how I swim about, happily unharmed in the boiling pitch." (Fides to Hadrian). "O mother... even as you pray... I feel no touch of pain." 26 (Spes to Sapientia). Hrotsvit's contribution to these episodes consists in developing the trait of impassibility even further, for the saints are able to predict the ineffectiveness of the torture. They are, therefore, more conscious of their own invulnerability, which is certainty less evident in earlier legends. Thus Agape voices her trust in God's power that will make fire forget its nature (which actually happens); Irena openly declares that she will never see the brothel, where they intended to take her; Spes promises an unpleasant surprise for her executioners, who are hoping that they will be able to silence her with torments; and even little Caritas firmly believes in the invulnerability of her body. The strongest proof of impassivity, however, is given by the mother, Sapientia, who witnesses the torture and death of her three children and surrenders them to God without one word of pain or sorrow. ${ }^{27}$

The indifference to physical torture is not an uncommon element in the martyr legends that served as sources for Hrotsvit's plays. Therefore, we do not mean to assert that there are specific texts that influenced her writing of these works. But there is no doubt that she was very susceptible to the symbolic meaning of the martyrdom, as the choice of the two motifs proves. Furthermore, in Sapientia and Dulci-

${ }^{24}$ Sapientia opens with a learned lesson of arithmology, given to Emperor Hadrian by the young girls' mother (Sapientia, no less) to "puzzle his dull brain."

${ }^{25}$ Fides, Spes and Caritas all show the characteristics of a puer senex, an "old child," which was a common figure in the child saints' cult (see Healy Wasyliw, Martyrdom, Murder and Magic, 43 and 54s.). In the present case, this characteristic is even more appropriately applied to the personifications of the three timeless Christian virtues. fante).

${ }^{26}$ Sap., pp. 256, 12 and 256, 26s.; p. 258, 30-259, 3 Berschin (transl. by L. Bon-

${ }^{27}$ Hrotsvit's characterization presents a contrast to the one made by J. of Voragine, who claims that Sophia has risen above martyrdom, since she had born the sufferings of her three children. 
tius, she chose two martyr legends, the protagonists of which are evidently personifications, which renders the human tone of drama superfluous, if not inappropriate. The impassivity of body and soul is perfectly natural, in view of the symbolic explanation, for how can the torture of three mortal girls, named Fides, Spes and Caritas, affect their spiritual namesakes, Faith, Hope and Charity, the three theological virtues? Their murder is no more than a blind attempt to harm something that cannot be harmed. ${ }^{28}$

Hrotsvit herself confesses to the use of certain apocryphal works when writing her own. Although she pleads an error ignorantiae, the uncertain credibility of these sources did not prevent her from continuing her work, hoping, as she says, that "what appears to be false, may eventually be proved to be true." ${ }^{29}$ It is also possible that in writing Agnes, she used sources considered apocryphal. ${ }^{30}$ In any case, there is no doubt that the motif of the impassibility of the body and soul in her works is carried to extremes. Her martyr's victorious and unyielding declarations present an obvious contrast of the human picture of Christ's Passion. Jesus feels deeply the horror of the impending torture and death, and prays that this cup be taken from him. In a moment of suffering, he says: "I thirst." The human image that reveals his human sufferings brought him nearer to the first Christians, who were likewise persecuted for their faith. ${ }^{31}$ The images of Christian martyrs, on the contrary, became more sublime as the centuries passed, until they were so indifferent to torture as to become mere personifications or symbols, clearly stating that these mutilated bodies are not theirs. These martyrs are showing inhuman strength that we neither seek nor find in the Passion of Christ.

${ }^{28}$ St. Agnes, indeed, with her human fears and sorrows, stands out among these fearless children, certain of their reward.

${ }^{29}$ Preface to Maria, 16 (transl. by G. Wiegand). The subjects of her Historia nativitatis (Maria) and Ascensio are borrowed from the apocryphal descriptions of Jesus' youth (cf. in particular the apocryphal gospels of St. James and St. Mathew). The apocryphal Acts of John were the source for her drama, Callimachus (see Wiegant, "The Apocrypha" in: The Non-Dramatic Works of Hrotswitha, 3-5).

30 These versions, like Hrotsvit's, contain the trial by fire: In the Syriac version ( $9^{\text {th }} / 10^{\text {th }}$ cent.), the saint is even burnt as a witch (see Asseman's Acta sanctorum martyrum Orientalium et Occidentalium in duas partes distributa, pars II: Acta Sanctorum Martyrum Occidentalium, qui sub variis Romanorum imperatoribus passi sunt, p. 164). The report of the trial by fire was also considered apocryphal by the $19^{\text {th }}$ century hagiographer, Sabine Baring Gould (Virgin Saints and Martyrs, 51s.). A probable source for Hrotsvit's Agnes are Acta, attributed to St. Ambrose, for they include the post-mortal miracles of the saint, which influenced the life of the emperor's daughter, Constance, and her suitor, Gallicanus (see Hrotsvit's play, Gallicanus). Other sources are Ambrose's, Prudentius' and Damasus' versions of her legend, but they mostly (with the exception of Damasus' inscription) do not include the ordeal by fire.

${ }^{31}$ Pagels, The Gnostic Gospels, 101. 


\section{Alchemistic "Torture" of Matter and Transformation of the Flesh}

The question of the value of martyrdom was part of the abovementioned controversy about the resurrection or, more accurately, regeneration of the body. Christian apologists, such as Tertullianus, used to point out that it is not the dead body that will rise again - for it is subject to decay - but that it is the flesh that is imperishable. From this flesh, as from a seed, a new, but the same body will rise again. ${ }^{32}$ Thus, the physical immortality was secured, even for those martyrs whose bodies were lost in the bellies of the beasts in the arenas. For martyrs, the belief in the indestructability of their flesh was of great importance, and was supposed to have mitigated their ordeals. ${ }^{33}$ In time, though, the martyr legends developed a doctrine according to which the torture of the body is imperative for the salvation of the soul. Fasting and other forms of self-denial were always considered as necessary exertions that made the body fit to be the companion of the soul on the day of resurrection. The martyrdom is a radical, yet in the eyes of some, a necessary form of purification. St. Agatha in The Golden Legend (p. 155) says: "The wheat cannot be stored in the barn unless it has been thoroughly threshed and separated from the chaff: So my soul cannot enter paradise, unless you make the headsmen give my body harsh treatment." These words, however, may not reveal more than the conviction that the body must be oppressed for the soul to be delivered. But in some of the martyr legends, the "harsh treatment" turns out to be beneficial not only to the soul, but to the body itself, which emerges from the ordeal transformed.

A frequent method of torture in the female martyrs' legends is the mutilation of breasts. ${ }^{34}$ To this trial, Hrotsvit's Fides is also subjected, and when the executioner cuts of her nipples, milk flows out of her wounds instead of blood. The motif is common enough in martyr legends, male as well as female (only in the case of male martyrs, the milk flows out of different wounds, e.g. from the neck, after decapitation). In these legends, the transformation leads to a kind of improvement, or even refinement, of the tortured flesh, strongly resembling the alchemical process of the "torture of matter." Alchemistic texts were used to support not only Gnostic doctrines of physical and spiritual purification, but orthodox Christian, as well, ${ }^{35}$ especially when it

${ }^{32}$ Inspired by St. Paul's image of seed (1 Corinth 15, 35 ss.), Christian apologists introduced numerous naturalist images into their arguments, defending the resurrection of the flesh (see, Walker Bynum, "Images of the Resurrection Body," 218-227).

${ }^{33}$ Ibid. 229.

${ }^{34}$ As in the case of St. Barbara (see Mills, Suspended animation, 106-108 and 113-118); also St. Agatha and St. Christina were subjected to similar torture.

${ }^{35}$ See Pereira, "Mater Alchimia," xvii. Analogous to the alchemistic process of the perfection of metals, was the spiritual transmutation, which resulted in the development of gnosis (see Voss, "Spiritual Alchemy," 149-175). On the redemptive power of the 
came to defending the resurrection and immortality of the body, as well as of the soul. In these cases, however, we are no longer speaking of the regeneration of the risen body, in the Tertullian's sense of the word ${ }^{36}$ but of the metamorphosis of the body, completed during the ordeal itself. ${ }^{37}$

Research suggests that the motif of milk flowing out of cut-off breasts has a medical background, and is based on the ancient theories of Hippocrates and Galen, asserting the joint nature of blood and milk, and alleging that the latter originates in blood. ${ }^{38}$ Hippocrates also mentions the unnatural state of the secretion of milk in the breasts of women who never gave birth (nullipara). The medical theory alone, however, is not responsible for the spread of the motif of a virgin's milk (lac virginis) in the Medieval legends of female virgin martyrs. The motif has roots in the cult of the Virgin Mother Mary, enriched with the image of the nursing virgin (virgo lactans) ${ }^{39}$ The image of virgo lactans goes back to the cult of the Egyptian goddess, Isis (nursing Horos), and is connected to the symbolism (known also in the Bible) of milk as liquid that gives life and knowledge. ${ }^{40}$ Accordingly, many Christian legends dwell on the Virgin's milk's power to increase knowledge and faith (as in the case of St. Bernard, nursed by Virgin Mary), and the Virgin's milk was frequently identified with the Eucharist. ${ }^{41}$ Scenes of childbirth and breastfeeding in one of the oldest Acta, narrating the martyrdom of St. Perpetua and St. Felicita, are believed to bear hidden messages related to the symbolism of breast milk. ${ }^{42}$

Ars magna, and its role in Christianity (particularly in the symbolism of its rituals), see Batfroi, La via dell'alchimia cristiana, 29-42.

${ }^{36}$ De resurrectione carnis, $60-61$.

${ }^{37}$ In the case of virgin martyrs, the physical metamorphosis was often preceded by a spiritual one, as Campbell points out (Medieval Saints' Lives, 57-60). Campbell gives the examples of St. Agnes and St. Euphrosyne who, by rejecting the marriage status and giving themselves to Christ, seem to experience a spiritual transformation which, in the case of St. Euphrosyne, is reflected in her taking the name of Esmerade (Emerald), the precious stone, the characteristics of which she has assumed.

${ }^{38}$ See Barry, "Martyr's Milk," 562-567, who refers to the Egyptian medical tradition, where milk (and breast milk in particular) was highly appreciated for its healing effects. Barry also indicates the relation between cults of St. Christine, who also had her breasts cut off, with milk flowing out of the wounds, and St. Pantaleon, the patron of healers (Ibid., 570).

${ }^{39}$ See, Walker Bynum, Holly Feast and Holly Fast, 269-276. The earliest representation of the Virgin Mother, nursing the child Jesus, is preserved in the early Christian tombs (Priscila, $2^{\text {nd }}$ Cent.).

${ }^{40}$ Warner, Alone of All Her Sex, 195ss.

${ }^{41}$ The assimilation of milk and blood had led to the analogous representations of Christ offering the blood from his wound (see Walker Bynum, Holly Feast and Holly Fast, 271s.).

42 Warner, Alone of All Her Sex, 198, understands it in a Gnostic context. Musurillo in The Acts of Christian Marytrs, xxvi, on the other hand, points out the similarities with the pregnant woman of Revelation 12 , and sees in this imagery a relation to the Montanists. 
Hrotsvit's interest in this motif shows nothing extraordinary: ${ }^{43}$ The scene with Fides must be borrowed from her sources, ${ }^{44}$ and pictures (Christian) Faith, shedding knowledge and faith in the form of virgins' milk. There may not be much more to this scene, but there is another one with her sister, Spes (Hope), which gives her a deeper meaning. Among all Hrotsvit's virgins, Spes is subjected to the cruelest torments: She is racked, lacerated with claws and bathed in hot pitch and wax, before they behead her. With Spes, the elements of physical invulnerability are somewhat paradoxically incorporated into the message that the perfection of the body is achieved through torture: While she remains impassive, body and soul, through some of her trials, her flesh, on the other hand, is exuding sweet odors, when she is being torn up with claws. The bodies of martyrs were generally believed to be different from those of ordinary people: One of their peculiarities was that they responded differently when wounded or hurt. ${ }^{45}$ However, this particular scene is Hrotsvit's addition to the story and, following the one with milk flowing out of Fides' wounds, reinforces the idea of bodily transformation through torture, and gives to the scenes of purification of the body through torture an alchemistic undertone. Periods after Hrotsvit's lifetime witnessed an upturn of alchemistic interpretations of Christ's incarnation and passion: ${ }^{46}$ In $14^{\text {th }}$ century, Peter Bonus compared the death and resurrection of the philosopher's stone with the martyrdom and beatification of the saints. Moreover, the virgin's milk, lac virginis, became one of the most important alchemistic symbols as a source of life, symbol of immortality and sometimes identified with the philosopher's stone itself. ${ }^{47}$ Its alchemical meaning, however, may be much older, and is supposed to be related to the image of the nursing virgin, be it Nature, Mary or Isis. ${ }^{48}$

${ }^{43}$ She obviously shared the belief in the powers of mother's milk, for in Gongolfus, she describes how the saint has imbibed the secrets of Christian faith with his mother's milk (Lac quoties suxit, toties fidei sacra sumpsit; Gongolfus, 41).

${ }^{44}$ Acta Sanctorum 1 August, I, 19 referring to Medieval writers such as Ado, Usuard and Notker, include the episode in the outline of the legend.

${ }^{45}$ Scented flesh and milk coming out of a wound, instead of blood, was one of the symptoms betrayed by the martyr's perfected body which, particularly among female saints, was believed to have lost its mundane nature (Walker Bynum, Holy Feast and Holly Fast, 274).

${ }^{46}$ See Huges, The Rise of Alchemy in Fourteenth-Century England, 48-54. Christ was identified with the Philosopher's Stone, Mercury, purified through its "torture" in Sulphur (the body).

${ }^{47}$ A good example of the symbolic meaning of the Virgin's milk is the image of the alchemical fountain in Rosarium philosophorum ( $16^{\text {th }}$ cent.), where the lac virginis represents one of the three primordial waters (together with accetum fontis and aqua vitae), mingling into one source of life (plate 1). The entire series of these plates pictures the process of perfection of the body in its Christian framework.

48 The latter, nursing Horos, is interpreted in the context of chromatic transmutation of the black (virgin) matter during the alchemistic process, called leikosis (or albedo, whitening); see Aaron Cheak, "Waters Animating and Annihilating," in Occult Traditions, ed. Damon Zacharias Lycourinos (Numen Books, 2012), 61s. 
Without trying to impute an explicit and daring use of either Gnostic or alchemical texts upon the work of Hrotsvit, we can safely say that her portraits of martyrs express the way these ideas were influencing the evolution of the ideal of martyrdom, the evolution which, in her works, reaches one of its most mature stages. In this context, we can also better understand the inhuman portrait of her heroines, victoriously proclaiming the ideals hidden behind their names.

\section{REFERENCES}

Barry, Philips. "Martyr's Milk." The Open Court (September 1914): 560-573.

Batfroi, Séverin. La via dell'alchimia cristiana. Traduzione dal francese di Pasquale Faccia. Roma: Edizioni Arkeios, 2007.

Berschin, Walter, ed., Hrosvit: Opera omnia (Bibliotheca Scriptorum Graecorum et Romanorum Teubneriana). Munich and Leipzig: W.G. Saur Verlag, 2001.

Bonfante, Larissa, trans., Chipok, Robert ed. Hrotswitha of Gandersheim Bilingual. Mundelein: Bolchazy-Carducci Publishers, 2014.

Campbell, Emma. Medieval Saints' Lives. The Gift, Kinship and Community in Old French Hagiography. Cambridge: D. S. Brewer, 2008.

Carlson, Marla. "Impassive Bodies. Hrotsvit Stages Martyrdom." Theatre Journal 50/4 (1998): 473- 487.

Cheak, Aaron. "Waters Animating and Annihilating." In: Occult Traditions. Edited by Damon Zacharias Lycourinos. Numen Books, 2012.

Coon, Lynda L. Sacred Fictions. Holy Women and Hagiography in Late Antiquity. Philadelphia: University of Pennsylvania Press, 1997.

Delaney, Sheila. Impolitic Bodies. Poetry, Saints, and Society in Fifteenth-Century England. Oxford University Press, 1998.

Dronke, Peter. Women Writers of the Middle Ages. Cambridge University Press, 1984.

Gravdal, Kathryn. Ravishing Maidens. Writing Rape in Medieval French Literature and Law. Philadelphia: University of Pennsylvania Press, 2010.

Healy Wasyliw, Patricia. Martyrdom, Murder, and Magic: Child Saints and Their Cults in Medieval Europe. New York-Oxford: Peter Lang, 2008.

Huges, Jonathan. The Rise of Alchemy in Fourteenth-Century England. London: Continuum, 2012.

Jonas, Hans. The Gnostic Religion. Boston: Beacon Pres, 1958.

Karras, Ruth Mazo. "Holy Harlots: Prostitute Saints in Medieval Legend." Journal of the History of Sexuality 1/1 (1990): 3-32.

Mills, Robert. Suspended Animation: Pain, Pleasure and Punishment in Medieval Culture. London: Reaktion Books, 2006.

Musurillo, Herbert trans. The Acts of the Christian Martyrs. Oxford: Clarendon Press, 1972. 
Newman, Florence. "Violence and Virginity in Hrotsvit's Dramas." In Hrotsvit of Gandersheim. Contexts, Identities, Affinities, and Performances. Edited by Phyllis R. Brown, Linda A. McMillin and Katharina M. Wilson. Toronto-Buffalo-London: Toronto University Press, 2004.

Pagles, Elaine. The Gnostic Gospels. New York: Vintage Books Edition, 1989.

Pereira, Michela. "Mater Alchimia. Trasformazione della materia e cura del mondo". In: Alchimia. I testi della tradizione occidentale. A cura di Michela Pereira. Milano: Mondadori, 2006.

Robinson, James M. ed. The Nag Hammadi Library in English. Third and completely revised edition. San Francisco: Harper Collins, 1990.

Salih, Sarah. Versions of Virginity in Late Medieval England. Cambridge: D. S. Brewer, 2001.

Jacobus de Voragine. The Golden Legend. Readings on the Saints. Translated by William Granger Ryan. Princeton and Oxford: Princeton University Press, 1993.

Sticca, Sandro. The Latin Passion Play: Its Origins and Development. Albany: State University of New York Press, 1970.

Sticca, Sandro. "Hrotswitha's 'Dulcitius' and Christian Symbolism." Medieval Studies 32 (1970): 108-127.

Van Elk, Martine. "'When female weakness triumphs': Torture and Perversion in Four Plays by Hrotsvit of Gandersheim." In Gender Reconstructions: Pornography and Perversion in Literature and Culture. Edited by Cindy Carlson, Robert L. Mazzola and Susan Bernardo. Routledge, 2017: 1-24.

Voss, Karen Claire. "Spiritual Alchemy: Interpreting Representative Texts and Images." In Gnosis and Hermeticism from Antiquity to Modern Times. Edited by Roelf van den Broek and Wouter J. Hanegraaff. Albany: State University of New York Press, 1998: 147-182.

Wailes, Stephen L. "Beyond Virginity: Flesh and Spirit in the Plays of Hrotsvit of Gandersheim." Speculum 76/1 (2001): 1-27.

Wailes, Stephen L. "Hrotsvit's Plays." In Brill's Companions to the Christian Tradition. A Companion to Hrotsvit of Gandersheim (fl. 960). Edited by Christopher M. Bellitto. Leiden-Boston: Brill, 2013: 121-145.

Walker Bynum, Caroline. Holy Feast and Holy Fast: The Religious Significance of Food to Medieval Women. Berkeley-Los Angeles-London. University of California Press, 1987.

Walker Bynum, Caroline. Resurrection of the Body. New York: Columbia University Press, 1995.

Walker Bynum, Caroline. "Images of the Resurrection Body in the Theology of Late Antiquity." The Catholic Historical Review 80/2 (1994): 215-237.

Warner, Marina. Alone of All Her Sex: The Myth and the Cult of the Virgin Mary. Oxford University Press, 2016.

Wiegand, Gonsalva M., trans. The Non-Drammatic Works of Hrotswitha. Text, Translation and Commentary. Diss., St. Louis, Missouri: University of St. Louis, 1936.

Wilson, Katharina M. "The Saxon Canoness: Hrotsvit of Gandersheim." In Medieval Women Writers, edited by Katharina M. Wilson. Athens: University of Georgia Press, 1984: 30-63.

Wilson, Katharina M., trans. The Plays of Hrotsvit of Gandersheim. New York-London: Garland Publishing, 1989.

Winstead, Karen Anne. Virgin Martyrs: Legends of Sainthood in Late Medieval England. Ithaca and London: Cornell University Press, 1997. 
